\title{
ARCHAEOLOGY HAS TRANSFORMED "STONES" INTO "HERITAGE": THE PRODUCTION OF A HERITAGE SITE THROUGH INTERACTIONS AMONG ARCHAEOLOGY, TOURISM, AND LOCAL COMMUNITIES IN TURKEY
}

\author{
A Arqueologia transformou "pedras" em \\ "patrimônio": a produção de um patrimônio através \\ da interação entre arquologia, turismo e comunidade \\ local na Turquia
}

\author{
Eisuke Tanaka*
}

\begin{abstract}
This paper explores how archaeology changes the relationship between different interest groups and the material remains of the past, in the context of archaeological excavation and tourism development. This paper uses the case of Patara, a small resort village in southern Turkey, to examine the role of historical sites marked as "heritage" in the context of archaeological excavation and tourism development. In particular, it focuses on how the relationships among locals, archaeologists, tourists, and the remains of the ancient city of Patara have been changed through the progress of archaeological excavations and the ensuing heritage management. In analyzing the process of archaeological excavation and tourism development in Patara, this paper also suggests that the excavated archaeological site of Patara itself works in changing the relationships among various groups with vested interests in the site.
\end{abstract}

Keywords: archaeology; heritage protection; excavation; tourism; Turkey

* Associate Professor. Fukuoka Jo Gakuin University, Osa 3-42-1, Minami-ku, Fukuoka 811-1313, JAPAN. E-mail: e_tanaka@fukujo.ac.jp 


\section{RÉSUMÉ}

Ce texte s'intéresse à la manière dont l'archéologie transforme la relation entre différents groupes d'intérêts et les vestiges du passé dans le contexte de fouilles archéologiques et de développement touristique. Pour cela, il étudie le cas de Patara, petit village d'un complexe touristique au Sud de la Turquie, pour saisir le rôle de sites historiques étiquetés comme étant du «patrimoine » dans le contexte de fouilles archéologiques et de développement touristique. Plus précisément, ce texte s'intéresse aux manières dont les relations entre locaux, archéologues, touristes et ruines de l'ancienne ville de Patara ont progressivement changé durant le déroulement des fouilles archéologiques et la gestion du patrimoine qui s'en est suivie. À travers l'analyse du processus de fouilles archéologiques et de développement touristique à Patara, ce texte suggère aussi que le site archéologique fouillé de Patara est lui-même un acteur des transformations des relations entre les différents groupes ayant des intérêts directs pour le site.

Mots-clés: archéologie; protection du patrimoine; fouilles archéologiques; tourisme; Turquie

\section{RESUMO}

Este texto investiga a maneira como a arqueologia modifica as relações entre vários grupos de interesses e vestígios do passado no contexto de escavações arqueológicas e de desenvolvimento turístico. Para isso, ele estuda o caso de Patara, pequena aldeia resort no Sul da Turquia, para entender o papel de sítios históricos qualificados como "patrimônio" no contexto de escavações arqueológicas e de desenvolvimento turístico. Mais especificamente, este texto investiga como as relações entre os atores locais, os arqueólogos, os turistas e os vestígios da antiga cidade de Patara progressivamente mudaram enquanto se foram realizando as escavações arqueológicas e, em seguida, a gestão do patrimônio. Por meio da análise do processo de escavações e do desenvolvimento turístico em Patara, sugere-se que o sítio escavado mesmo é um ator das transformações das relações entre os diferentes grupos que se interessaram pelo sitio.

Palavras-chave: arqueologia; proteção do patrimônio; escavação; turismo; Turquia 


\section{Introduction}

In Turkey, the protection of heritage sites is a focal point of public attention. Mainly due to its geopolitical location, the country has been considered archaeologically as well as historically "rich" (ÖZDOĞAN, 1998). The large number of archaeological and historical sites include globally known tourist destinations, such as Ephesus, Pergamon, and the historic quarters of Istanbul, many of which feature on UNESCO's World Heritage List. ${ }^{1}$ As of 2009, there were more than 114,000 protected heritage properties (BONINI BARALDI et al., 2013, p. 733), 7,766 of which are registered as archaeological sites. Many more archaeological sites have yet to be registered.

The balance between tourism development and heritage management has become a contentious issue because the tourism sector is a very important source of income for the Turkish economy. In fact, the country attracted approximately 39 million international tourists in 2014, which makes it among the top 10 tourism destinations worldwide in terms of international tourism arrivals (UNWTO, 2015). In particular, the development of tourism has concentrated on the Aegean and the Mediterranean coasts since the 1960s, transforming coastal towns and villages in the region into tourist resorts for both domestic and foreign tourists (KEYDER, 2003 , p. 50). The increase in threats to the preservation of the large number of archaeological sites in the region parallels the rapid increase in the numbers of visitors to Turkey. The Turkish government has set up a strict legal framework to protect these archaeological sites. However, this may be a source of conflict between archaeologists and locals, especially those who want to exploit their lands for development.

This paper explores how the development of a heritage site changes the relationship that people and organizations with an interest in heritage - such as archaeologists, local government, locals, and tourists - have with the archaeological remains. It focuses on the case

1 http://whc.unesco.org/en/statesparties/tr 
of Patara, on the Mediterranean coast of southern Turkey, where tourism development and archaeological excavation arrived almost simultaneously. Initially, the relationship between archaeologists and the locals, who wanted to promote tourism, was not a cordial one. However, as the remains of the ancient city of Patara emerged from the sands through excavations and subsequent restorations, the nature of the relationship between the archaeologists and the locals gradually changed. This paper examines the role of things marked as "heritage," in the context of both archaeological excavation and the development of tourism. In particular, it looks at how the relationships among the different stakeholders were constituted and changed during the progress of the archaeological excavations and the heritage management that followed.

\section{Heritage as a social process}

Recent studies on heritage have critically examined in what way cultural manifestations, both tangible and intangible, are transformed into "heritage" (e.g. BARTU-CANDAN, 2007; BENDIX, 2009; HAMILAKIS, 2007; HANDLER, 1988; HERZFELD, 1991; KIRSCHENBLATT-GIMBLETT, 1998; LOWENTHAL, 1998; SMITH, 2006). With heritage status, culture becomes subject to protection and special care. This is because heritage is generally regarded as a threatened, non-renewable resource, and one that therefore should be protected and preserved as much as possible for future generations (CLEERE, 2000; cf. APPADURAI, 1981). Given that heritage plays an important role in the formation of cultural identities, nations and ethnic groups conceive of the preservation and conservation of cultural objects as a matter of establishing and protecting their identity. For archaeologists, protecting heritage is a professional "responsibility" in the sense that archaeological remains can be seen as a database for understanding the past and thus "heritage" (CLEERE, 2000, p. 9-10). International heritage-related agencies similarly consider themselves 
responsible for the preservation and conservation of heritage as a threatened resource (CLEERE, 2000, p. 5).

When critically examining such production and reproduction of the discourse on heritage protection, many scholars have pointed out that expert knowledge and practices have been implicated in the construction of the dominant heritage discourse, at the expense of local narratives of the past (e.g. FOG OLWIG, 1999; SMITH, 2004, 2006). For example, Laurajane Smith discusses what embodies such dominant assumptions about the nature and meaning of heritage, which she calls the "authorized heritage discourse" (SMITH, 2006). The concept of "authorized heritage discourse" can also be applied to the construction of the Afro-Caribbean past, and Karen Fog Olwig suggests that the "global" discourse of "heritage" marginalizes "local" narratives of the past (FOG OLWIG, 1999). As a result, heritage is now considered to be open to multiple interpretations. Expert knowledge can no longer be presumed to take precedence over other stakeholders' interpretations, although it is still influential in defining remains of the past as "heritage" (e.g. BREGLIA, 2006; GRAHAM et al., 2007; MATHERS et al., 2005; MESKELL, 2009; MESKELL and PELS, 2005).

Given the plurality of interpretations and narratives of heritage, it is important to look at heritage as a social process, in which different groups of people interact with each other in order to engage with cultural manifestations marked as "heritage." This also means that heritage emerges from conflictive interactions among different stakeholders and that those things identified as "heritage" are formed in this process (HARRISON, 2013).

In discussing the construction of heritage in this way, Anna Tsing's argument on interconnections between the local and the global is useful. Analysing the cultural and political dynamics of the ways in which various local, national, and global actors interpret and engage with the protection of the rainforests of South Kalimantan, Indonesia, Tsing argues that a "global connection" is produced through the interconnection between different actors and capitalist or environmentalist dreams and schemes (TSING, 2005). She describes the diverse and conflicting social interactions between different groups as "friction," which she defines as "the awkward, unequal, 
unstable, and creative qualities of interconnection across difference" (TSING, 2005, p. 4).

Explaining the work of friction, Tsing also appeals to the notion of "collaboration" as a broader sense of working together. For her, collaboration does not simply mean working towards consensus, but includes situations where "the collaborators are not positioned in equality or sameness, and their collaboration does not produce a communal good." Collaborators, she says, "may or may not have common understandings of the problem and the product" (TSING, 2005 , p. 246-247). Moreover, collaborators "may or may not have any understanding of each other's agenda" (TSING, 2005, p. 247).

Using the case of Patara in southern Turkey, I discuss the way in which archaeology has changed the local life around the remains of the ancient city that are marked as "heritage" areas. Before we look at the production of heritage through the interactions between different groups of people in Patara in detail, it is important to understand the legal and administrative framework of heritage protection in Turkey. I argue that collaboration between different stakeholders invested in the ancient city's remains is an essential component in the protection and development of the heritage of these remains.

\section{The Legal and Administrative Framework for Heritage Protection in Turkey}

As previously mentioned, there are a huge number of historical and archaeological sites in Turkey. The Turkish state has exerted its ownership over all cultural materials found in the country since its establishment in 1923 . $^{2}$ The current legislative framework for cultural heritage protection in the country is law no. 2863, on the 
protection of cultural and natural properties (Kültür ve Tabiat Varlıklarını Koruma Kanunu No. 2863), adopted in 1983. Turkey has also ratified several UNESCO and Council of Europe international conventions concerning heritage protection. Based on this legal framework, the heritage administration system in Turkey is characterized as both centralized and segmented (BONINI BARALDI et al., 2013, p. 730-732, see also Figure 1). The ministry of culture and tourism (Türkiye Cumhuriyet Kültür ve Turizm Bakanlığı) plays a central role in heritage management, and the general directorate of cultural heritage and museums (Kültür Varlıkları ve Müzeler Genel Müdürlüğü, 2013) in Ankara is its main body for central administration. The general directorate of cultural heritage and museums also controls a number of the museum directorates (Müze Müdürlüğü) as its regional bodies. These museum directorates, in turn, have responsibility for a specific geographic area to protect listed heritage sites, conduct and monitor excavations, and manage the national museums and ruins (ören yeri) open to the public (BONINI BARALDI et al., 2013, p. 730).

There are also several other institutions responsible for heritage management. While the general directorate of cultural heritage and museums is mainly responsible for pre-Islamic, i.e., prehistoric and classical Greek and Roman, heritage, the directorate general of foundations (Vakıflar Genel Müdürlüğ̈̈) ${ }^{3}$ manages Islamic and Ottoman heritage, mostly religious buildings (mosques and madrassas), but also historic urban architecture (BONINI BARALDI et al., 2013, p. 731). It should be noted that many of the foundations that the directorate general of foundations oversees are not historical and have no connection with heritage. charitable purposes (T.C. BAŞBAKANLIK VAKIFLAR GENEL MÜDÜRLÜĞÜ, 2011). 
Figure 1 Administrative framework of heritage protection in Turkey

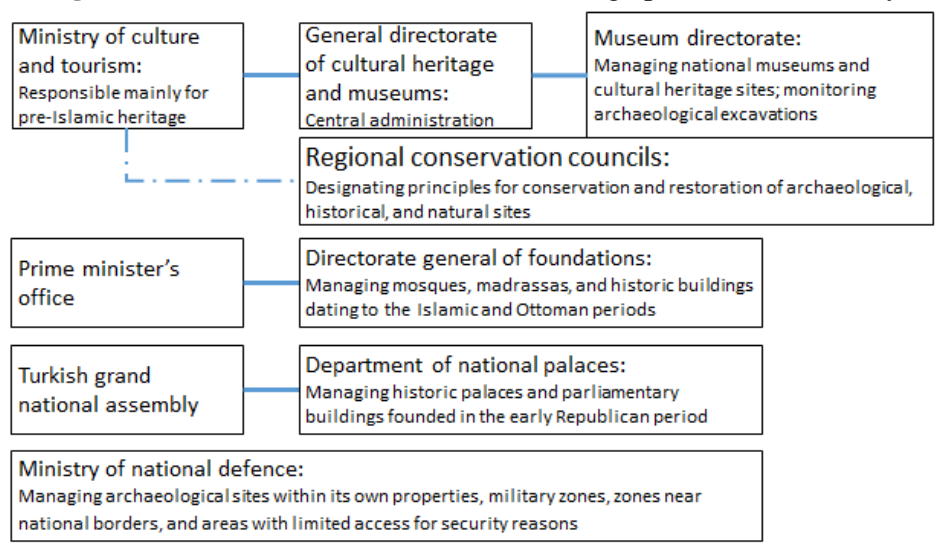

Moreover, the Turkish grand national assembly (Türkiye Büyük Millet Meclisi) has authority over historic palaces, such as the Dolmabahçe and Yıldız palaces on the Bosphorus, as well as mansions and parliamentary buildings, many of which were founded in the early years of the Turkish Republic (BONINI BARALDI et al., 2013, p. 731). ${ }^{4}$ The ministry of national defense (Millî Savunma Bakanlığ 1 ) also manages archaeological sites for protection within its own properties, military zones, and zones near national borders and areas having limited access for security reasons (BONINI BARALDI et al., 2013, p. 731).

In order to monitor the conservation and restoration of listed archaeological sites, 34 regional conservation councils (Kültür Varlıklarını Koruma Bölge Kurulu Müdürlükleri) are responsible for the conservation of cultural heritage. These regional conservation councils are affiliated with, but independent from, the ministry of culture and tourism in their decision making. According to law no. 2863, regional conservation councils are responsible for "scientifically guiding the intervention in immovable cultural and

4 The department of national palaces, as a unit within the general secretariat of the Turkish grand national assembly (TBMM Genel Sekreterliği Milli Saraylar), has responsibility for the management of these buildings (TBMM MILLI SARAYLAR, 2015). 
natural property throughout the country." They are specifically charged with "approving conservation or development interventions at listed sites" (law no. 2863, article 51, quoted in BONINI BARALDI et al., 2013, p. 731). The regional conservation councils consist of experts (archaeologists, natural scientists, city planners, and architects). These councils play a central role in designating principles for conservation and restoration on archaeological, historical, and natural sites and assisting the general directorate in implementing and evaluating the results (BONINI BARALDI et al., 2013, p. 730-731).

In particular, one of the duties of the regional conservation councils is to identify the physical boundaries of areas needing protection because of their cultural and natural properties. The resulting protected area is called sit alan in Turkish. They also decide the uses and restrictions of the site, by imposing one of three degrees of protection. In areas designated as first-degree protected areas (birinci derece sit alani), any activities that would affect the sites, except for archaeological excavations permitted by the general directorate of cultural heritage and museums, are strictly prohibited (ANTALYA İL KÜLTÜR VE TURIZM MÜDÜRLÜĞÜ, 2014). The classification as second-degree protected area (ikinci derece sit alani) means the protected site area will include any building already in place before the local regional conservation council's designation. In the second-degree protected areas, people can no longer construct new buildings. Local residential areas are usually designated as thirddegree protected areas (üçüncü derece sit alanı). In these areas, locals can construct or modify any buildings on condition they have an official permit from the local regional conservation council (ANTALYA İL KÜLTÜR VE TURIZM MÜDÜRLÜĞÜ, 2014).

Thus, the regional conservation council's site protection designation affects the everyday lives of local inhabitants living near or on archaeological sites. Moreover, protected areas are strictly controlled by the local museum directorates. When archaeologists conducting excavations at a site discover illegal land use by locals, they have to report it to the local museum directorate, who then fines those locals who violated the regulation.

Site excavations are also controlled by the general directorate under law no. 2863 (law no. 2863, articles 35-41). Archaeologists 
who intend to carry out excavations in Turkey have to apply for a permit from the general directorate by December of the preceding year. The general directorate sends a government inspector to each excavation site. The inspectors, who are officials with an archaeological background working at the museum directorates, are not necessarily sent to neighbouring archaeological sites. Staying at the excavation site throughout the excavation period, the inspector writes reports on the excavation's progress to the general directorate of cultural heritage and museums. The inspectors are usually sent to different excavation sites every year, although they would come back to the same site every two to three years.

As previously mentioned, Turkish archaeological remains are owned and managed by the state as "heritage" under to law no. 2863. Within this legal and administrative framework, the Turkish government becomes part of the collaborative process producing heritage sites. In the following sections, I look at this as a cause of concern to archaeologists and locals in relation to the aforementioned legal and administrative framework, focusing on the case of Patara.

\section{Commencement of Heritage Management and Tourism Development in Patara}

The archaeological site of Patara, which flourished as a port city on the Mediterranean coast of western Anatolia, is located two $\mathrm{km}$ from the centre of a small village called Gelemiş, whose current population is approximately 950. In addition to the ancient city remains, Patara is also known for being an area of outstanding natural beauty and of great environmental importance. The $18 \mathrm{~km}$ sandy beach with large sand dunes is considered ecologically important as it is one of the nesting sites for loggerhead sea turtles (Caretta caretta) on the Mediterranean coast of Turkey. Due to their natural and cultural significance, the remains of the ancient city of Patara and its surrounding area are designated as special areas for environmental 
protection (Özel Çevre Koruma Bölgesi) according to law no. 2872, on the environment (Çevre Kапипи No. 2872), implemented in 1990.

Figure 2 Map of Turkey showing the location of Patara

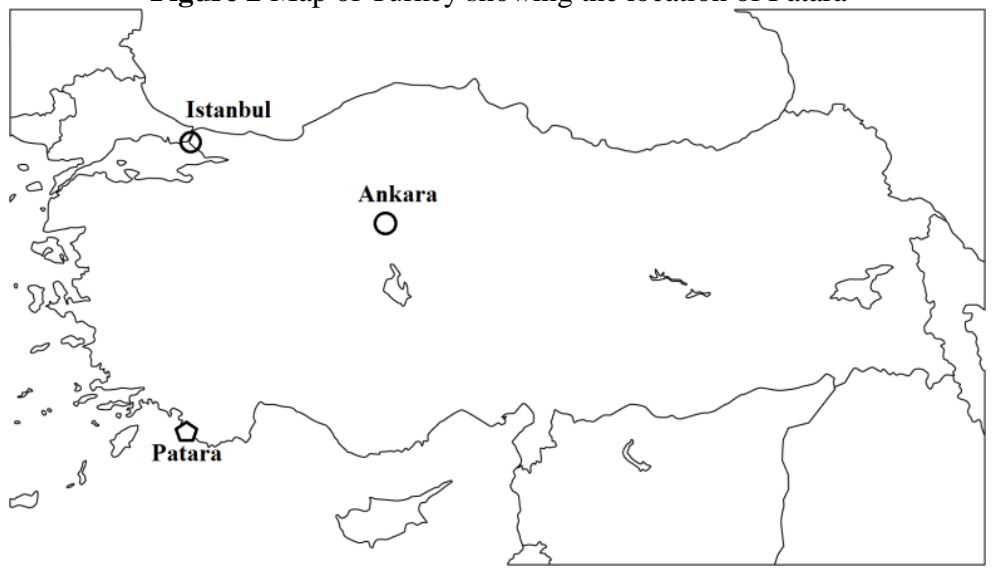

Archaeological evidence indicates that the first settlement at Patara was established in the early Bronze Age (IŞIK, 2011, p. 1618). In antiquity, Patara was noted for its temple and oracle of Apollo ${ }^{5}$ by historians such as Herodotus (IŞIK, 2011, p. 18). During the second century B.C., the city formed a league with other Lycian city states, the Lycian League. In the Lycian League, Patara was one of the most powerful states, as it was a strategically important port on the Lycian coast (IŞIK, 2011, p. 19). The city maintained its status as a regional centre under the rule of the Roman and Byzantine empires (IŞIK, 2011, p. 22), and it continued to be important in early Christianity given that the Bishop of Patara represented Lycia at the ecumenical councils (IŞIK, 2011, p. 22). It is also known as the birthplace of St. Nicholas of Myra, the person upon whom the story of Father Christmas is believed to be based (IŞIK, 2011, p. 22). 
Due to the Arab invasion of Anatolia and, later, the Black Death, Patara began to decline in the sixth century (IŞIK, 2011, p. 23). According to historical records, the city was considered to be abandoned by the sixteenth century (IŞIK, 2011, p. 24). In the eighteenth and nineteenth centuries, European travellers noted that the ruins were covered with sands and that there was no settlement except by nomadic people (yörük in Turkish), who camped at the site (YIIMAZ, 1996, p. 8). These European accounts actually confirm the local accounts about the history of Gelemiş, as locals claim that their grandfathers came to Patara for winter grazing, while in summer they stayed in the meadows of the Elmalı district, about $35 \mathrm{~km}$ inland from the coast (YILMAZ, 1996, p. 8).

Covered with sand and bushes, the abandoned city ruins of Patara were almost untouched when archaeological excavation started in the late 1980s. Until the 1950s, nomadic people came to Patara in the winter months to graze their goats and sheep, leaving only small farming shelters near the site (IŞIK, 2011, p. 24). The development of the village of Gelemiş began when it became an administrative unit in 1961. The village was originally established by eight families who lived a semi-nomadic life between Patara and the meadows of the Elmalı district. They eventually settled in the newly established village, where they started greenhouse farming. These closely related families often distinguished themselves from "foreigners" (yabancl), meaning other Turks who settled in the Gelemiş area later on. With the introduction of greenhouse cultivation and, later, tourism, most villagers abandoned their semi-nomadic life-style. However, some older people still maintain their traditional seasonal migration. They stay in the meadows in Elmalı district in summer, where they grow fruit, such as apples and pears, and they return to Gelemiş in winter for the milder coastal climate (MORRISON and SELMAN, 1991, p, 119).

The management of the ruins of Patara began in the late 1970s, when Patara was registered as a protected archaeological site by the ministry of culture (YILMAZ, 1996, p. 15). In 1981, the site was divided into three zones by the regional conservation council of Antalya, differentiating between areas that contained ruins and residential areas. Zones $\mathrm{A}$ and $\mathrm{B}$ covered the central part of the ancient city of Patara, while Zone $\mathrm{C}$ included the village centre of 
Gelemiş and part of the city's necropolis (YILMAZ, 1996, p. 17). In 1988, archaeologists from Akdeniz University in Antalya began excavations at Patara that continue today.

The number of tourists from Western Europe has increased since the early 1980s. Tourists were originally attracted to the beautiful beach, the climate, and the relatively low cost of visiting Turkey. This increase was also due, in part, to western media reporting on Patara's natural beauty (IŞIK, 2011, p. 24). Locals responded to this opportunity. In 1986, the first locally run guest house opened, and several others were developed in the following years (MORRISON and SELMAN, 1991, p. 118). The villagers initially financed the guest houses and hotels without outside investment. However, they gradually started to rent their rooms by signing contracts with European tour agencies. By the end of the 1980s, building development in the village had escalated, with many more inns, restaurants, and bars, often financed by people from outside the village (MORRISON and SELMAN, 1991, p. 118).

Tourists to the village concentrated on the sand beach for sunbathing and swimming, and the majority of the visitors went directly to the beach, walking across the ruins of ancient Patara. Some of the remains of Patara were even bulldozed during tourism development in the early 1980s (IŞIK, 2011, p. 115-117). Thinking that the rapid growth of the local tourism industry would result in the destruction of the archaeology site, the archaeologists working at Patara attempted to restrict the development of tourism, and in 1990, Fahri Işık, the director of the excavation team at that time, requested the government stop all new development in the village. In 1990, the archaeological site of Patara and surrounding areas, including its sand beach and dunes, became a special protected area. Moreover, Zone A was designated as a first-degree archaeological protected area, while Zone $\mathrm{C}$ (the village centre) became a third-degree archaeological protected area. Because of the archaeological significance of Patara, new development in the residential area of the village was also prohibited. Furthermore, with its recognition as a nesting site of sea turtles, the beach was also designated as a first-degree natural area (YILMAZ, 1996, p. 21).

Due to the implementation of these regulations, it became impossible for the villagers to expand their tourism business as they 
wished. This resulted in strained relationships between the excavation team and villagers who wished to sell their lands to developers from outside the village. In the mid-1990s, archaeologists had several meetings with the villagers and the local governor of Antalya, but they were unable reach an agreement on balancing tourism development and the protection of the site of Patara. Havva Işık, who is the current director of the excavation team, told me that it was very difficult to establish good relations with the locals until the late 1990s, implying that some locals showed hostility to the archaeological team. In fact, excavation areas were burnt down in several arson attacks (see also IŞIK, 2011, p. 115). As a result of the attempts by the archaeologists to stop tourism development, the village remains almost the same as it was 25 years ago - a small village with rambling houses. Most of the guest houses, hotels, bars, and restaurants are locally run.

\section{Changes in the relationship between archaeologists and locals since the 2000s}

Both the villagers and the archaeologists working at Patara explained that the centralized heritage administration of Turkey complicated these conflicts. Villagers who wished to exploit their lands for the tourism industry became hostile to the excavation team, who had requested that the ministry of culture designate the village as a protected area and prohibit further development. Although archaeologists insist that state regulation for site protection is necessary to save the ancient remains of Patara from the risk of destruction by construction of new buildings, they also point out that the centralised heritage management system does not work effectively. For example, the excavation at Patara started in 1988, but archaeologists had first applied to the Ministry of Culture for an excavation permit in 1981 (IŞIK, 2011, p. 115). Each year for seven years, their application was rejected, causing a seven-year delay for the beginning of excavations. Archaeologists claim that Patara could 
have remained untouched by the tourism industry had they received their permit earlier (IŞIK, 2011, p. 117).

The relationship between the archaeologists and the locals who expected benefits from the tourism industry gradually became less strained starting in the early 2000s. The current village head (muhtar in Turkish), who was elected in the early 2000s, has tried to foster a better relationship with the excavation team and to work for the protection of Patara.

Archaeologists working at Patara suggest that this new relationship is the result of progress made on the Patara excavations over 25 years, which has made the ancient ruins much more visible (compare Figure 3 and Figure 4) - uncovering the Mettius Modestus honorary arch, theatre, agora, temples, Lycian tombs and necropolis, Roman and medieval baths, Byzantine basilicas, and city walls thereby made it easier for tourists as well as locals to see the value of the archaeological remains of Patara as "heritage". Archaeologists emphasize that those results also helped to promote the local tourism industry.

Figure 3 The view of Patara from the theatre in the early 1990s

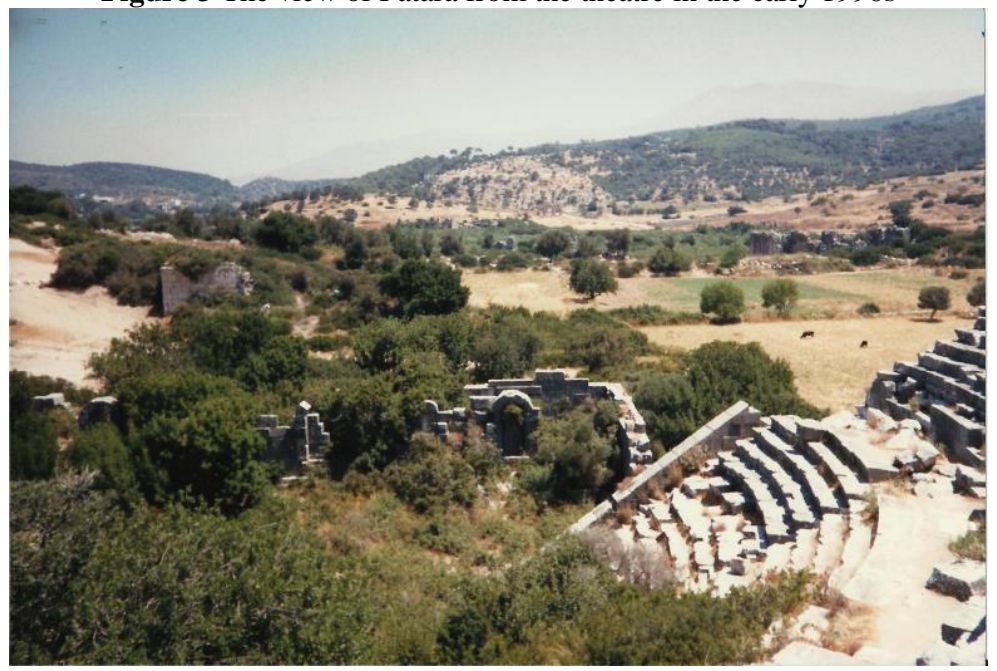

(Photo: Pamir Y1lmaz) 
Figure 4 The view of Patara from the theatre in 2012

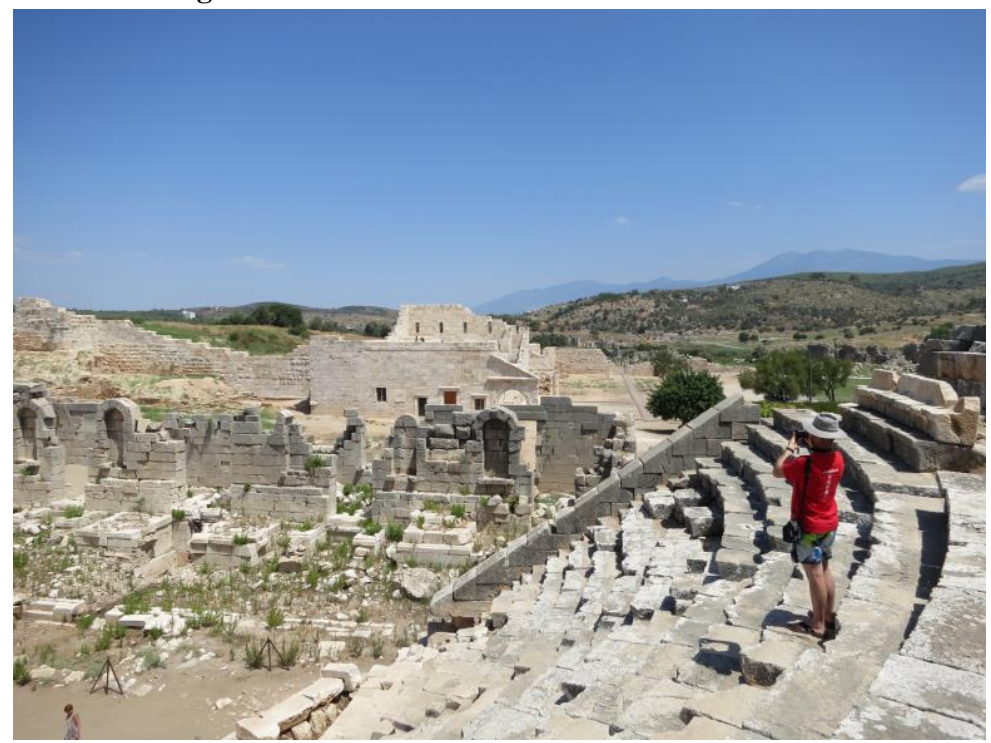

(Photo: Author)

One notable example is the excavation and restoration of the Lycian League assembly hall, or bouleuterion (Figure 5). Because Patara was the capital city of the ancient Lycian League, archaeologists view the bouleuterion at the core of ancient Patara as particularly important. In addition to having archaeological significance, this discovery had symbolic significance for the Turkish state, which was now able to emphasize the role of Patara as the birthplace of the Western democratic system in European Enlightenment thinking. ${ }^{6}$ The Grand National assembly of Turkey decided to support the cost of the restoration of the bouleuterion. Given the centralized nature of the heritage administration system, as previously discussed, it is unusual for the Turkish Grand National assembly to be involved in the restoration work of an archaeological Montesquieu referred to the Lycian League as a perfect confederation republic (IŞIK, 2011, p. 66). 
site. Arguably, for the Turkish parliament, the bouleuterion may be considered a political tool to proclaim that Turkey is the guardian of democracy (cf. SHOUP, 2006). The restoration work on the bouleuterion was completed in 2012, and the speaker of parliament attended its opening ceremony.

Figure 5 The restored bouleuterion, the assembly hall of the Lycian League

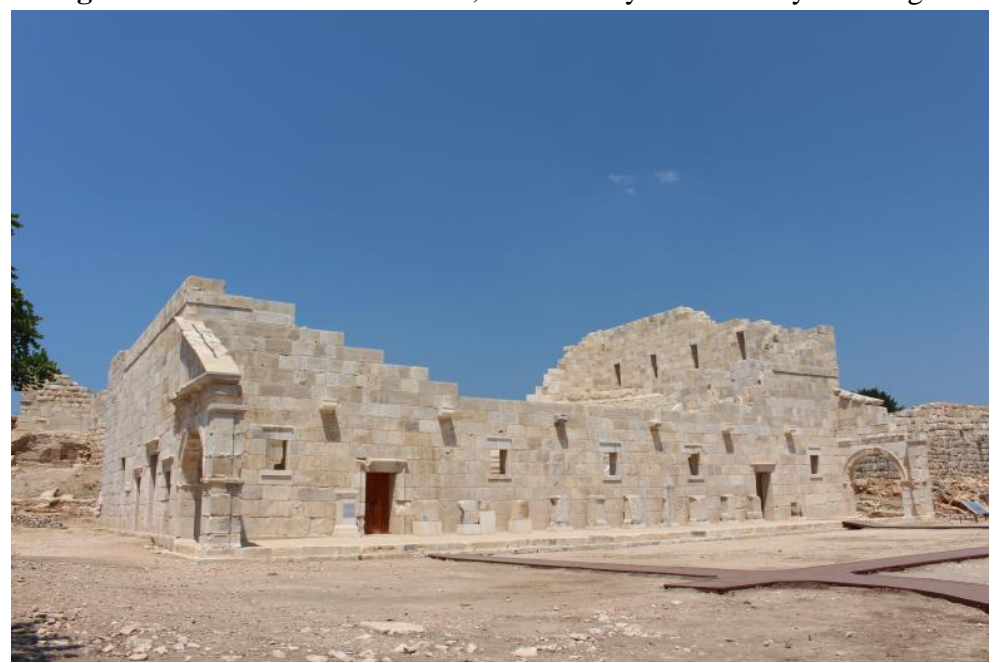

(Photo: Author)

As the remains of the ancient city emerged out of the sand, visitor facilities, such as a souvenir shop and toilets, were constructed. Information panels explaining the details of the site were also installed. As a result of this process, tourists gradually started visiting the ruins of Patara.

In parallel, the villagers started utilizing Patara as one of their tourism resources. The owners of the guest houses and hotels in the village established the Patara culture and tourism foundation (Patara Kültür ve Turizm Tanıtma Derneği) in 2012 to promote tourism in Patara to a broader public, and they published a brochure introducing Patara and the village. The members of the culture and tourism foundation also participated in various tourism fairs in Europe. 


\section{Constitution of the relationship among archaeology, different interest groups, and the material remains of the past}

I have attempted to show how archaeological excavations and restorations aided in transforming the ancient city remains of Patara into a heritage site. It is worth noting here that the "collaboration" (TSING, 2005) between the villagers and archaeologists cannot simply be explained through the dichotomic view of heritage protection versus tourism. This is indicated in the ways in which the idea of protection is mobilised by locals and archaeologists. Archaeologists wanted protection in order to stop construction projects associated with tourism in Patara when they started excavation in the late 1980s. But for locals, heritage protection became an obstacle for promoting tourism in their village. However, as the excavations over the years made the ruins of Patara more visible, heritage protection provided a new avenue for tourism.

For the villagers, balancing development and protection of Patara as "heritage" is becoming more and more important. When I asked the village head, who himself runs a guest house and a hotel in the village, about the relationship between tourism and archaeology, he replied: "We have become accustomed to the situation that we cannot do what we want to do. Once accustomed, we started communicating with archaeologists." Moreover, the villagers' view on the village and its tourism development is changing, especially when they compare the promotion of tourism in Patara with that in neighbouring towns. Referring to Kalkan, a neighbouring town that saw rapid development as a tourist resort attracting international tourists, the village head said:

\footnotetext{
"Kalkan developed quickly, but this created problems. It used to be a small fishermen's village. However, the villagers sold their lands to outside investors for the construction of holiday houses, and they are now employed by those outsiders. Looking at the situation in Kalkan, many of us, if not everyone, now think it much better to keep the village's atmosphere as a small village" (Alif Otlu, personal communication, August 2014).
} 
This attitude is also spelled out in the brochure published by the Patara culture and tourism foundation. The introduction says that, in the village,

life slows to a different pace where time can be forgotten and where visitors can quickly feel at home [...].

This small village, untouched by mass tourism is set in the foothills of the mountains, next to a wonderful $18 \mathrm{~km}$ sandy beach. Much of life here is geared around agriculture. Most of the locals have olive groves and fruit orchards, filled with tomatoes, cucumbers, aubergines, and peppers, and small plot of land on which they grow seasonal vegetables [...]. Clusters of traditional beehives can be found in the hills around the village, used for the production of delicious local honey (PATARA KÜLTÜR VE TURIZM TANITMA DERNEĞI, 2014, p. 6).

Thus, for the locals, this "untouched-ness" of village life brought about by the restrictions on tourism development at Patara is now seen as something to be protected and carefully promoted.

Archaeologists also point out that tourism in the village is now supported by the progress of the excavations at Patara. Given that what is archaeologically important does not always attract the interest of the locals or the tourists, some of the archaeologists admit that the villagers are not necessarily interested in archaeology itself, but, rather, that they expect "discoveries" that will promote tourism in the village. However, when discussing the changing relationships between archaeologists and the villagers, one of the archaeologists said to me, "Over the last ten years, the relations with the villagers have changed from 'hostile' to 'cooperative.' It was the villagers, not us, who started showing friendship." The shifting of local attitudes towards Patara, she adds, suggests that the villagers have started seeing the ruins as their "heritage" rather than "stones," even though they focus on the site's commercial aspects. 


\section{Conclusion}

This paper has the case of the ancient city of Patara to show how archaeological excavations may change the relationship among local people, archaeologists, and the actual archaeological site. In the case study presented here, these changes have been influenced by the economic and political situation of the modern-day village of Patara, such as the increased competition in tourism with neighbouring towns, like Kalkan, and state support for the restoration of the bouleuterion. The attitudes of the residents towards the ruins of Patara have changed through time. This shows that the interests of the archaeologists and the interests of locals wanting to promote tourism have become intricately linked, rather than being in opposition to each other. In Patara, archaeology was initiated to stop tourism development. However, once the site became visible, the archaeological work actually worked to reinforce the local tourism industry. The value of the remains of the ancient city of Patara as "heritage" for the locals in modern-day Patara was generated through these interactions.

This case study suggests that heritage protection functions as part of a social process. The notion of protection forms the common ground for "collaborations" between these interest groups. Heritage protection was divisive in the sense that it was initially mobilised to criticise tourism development in Patara. However at the same time, heritage protection has connected these different communities because the site of Patara has helped preserve the village, and has now become an important resource for the local tourism industry.

Finally, the changing relationships between locals and archaeologists demonstrate that what affects their relationship is the material remains discovered through archaeological excavations. Heritage is constituted not only through interactions among different interest groups, but also through interactions between these groups of people and the material remains discovered by archaeologists. 


\section{Acknowledgements}

The research was supported by JSPS KAKENHI Grant Number 26870789. I am particularly indebted to Pamir Y1lmaz, Ünal Demirer, and Mehmet Tuncer for their support during my research about the excavations at Patara. I am also grateful to Prof. Havva Işık, head of the Patara excavation team, for providing information about the Patara archaeological site and excavations. Finally, I would like to thank Allison Bain and Réginald Auger and the participants in the session "What does Heritage Change? Case Studies in Archaeology" at the 2016 Association of Critical Heritage Studies Conference for their interest and their useful comments.

\section{Bibliography}

ANTALYA İ KÜLTÜR VE TURIZM MÜDÜRLÜĞÜ. http://www.antalyakulturturizm.gov.tr/TR,67605/sit-alanlari-korumave-kullanma-kosullari.html, 2014 (accessed on 24.10.2016).

APPADURAI, A. The past as a scarce resource. Man (N.S.), n. 16 (2), p. 201-219.1981

BARTU-CANDAN, A. Remembering a 9000 years old site: presenting Çatalhöyük. In : ÖZYÜREK, E. (ed.) Politics of the Public Memory in Turkey. Syracuse: Syracuse University Press, 2007, p. 7094.

BENDIX, R. Heritage between economy and politics; an assessment from the perspective of cultural anthropology. SMITH, L. AKAGAWA, N. (eds.) Intangible Heritage. Oxford: Routledge, 2009, p.253-269.

BONINI BARALDI, S., SHOUP, D., and ZAN, L. Understanding cultural heritage in Turkey: institutional context and organizational 
issues. International Journal of Heritage Studies. n. 19(7), p. 728748, 2013.

BREGLIA, L. Monumental Ambivalence: the Politics of Heritage. Austin: University of Texas Press, 2006.

CLEERE, H. 2000. Introduction: the rationale of archaeological heritage management. In: CLEERE, H. (ed.) Archaeological Heritage Management in the Modern World. Oxford: Routledge, 1990, p. 1-19.

ELDEM, E. From blissful ignorance to anguished concern: Ottoman perceptions of antiquities, 1799-1869." In Bahrani, Z.; Çelik, Z.; Eldem E. (eds) Scramble for the Past: a Story of Archaeology in the Ottoman Empire, 1753-1914. Istanbul: SALT, 2011, p. 282-329.

FOG OLWIG, K. The burden of heritage: claiming a place for a West Indian culture. American Ethnologist. n. 26 (2), p. 370-388, 1999.

GRAHAM, B., ASHWORTH, G., TUNBRIDGE, J. E. (eds.) Pluralising Pasts: Heritage, Identity and Place in Multicultural Societies. London: Pluto Press, 2007.

HAMILAKIS Y. The Nation and Its Ruins: Antiquity, Archaeology, and National Imagination in Greece. Oxford: Oxford University Press, 2007.

HANDLER, R. Nationalism and the Politics of Culture in Quebec. Madison: The University of Wisconsin Press, 1988.

HARRISON, R. Heritage. London: Routedge, 2013.

HERZFELD, M. A Place in History: Social and Monumental Time in a Cretan Town. Princeton: Princeton University Press, 1991.

IŞIK, F. "Caput Gentis Lyciae”: Patara Lykia Soyunun Başkenti. Istanbul: Scala Matbaacilık, 2011.

KEYDER Ç. The Consequences of the exchange of populations for Turkey. In: HIRSCHORN, R. (ed.) Crossing the Aegean: an Appraisal of the 1923 Compulsory Population Exchange between Greece and Turkey. New York: Berghahn, 2003, p. 39-52. 
KIRSCHENBLATT-GIMBLETT B. Destination Culture: Tourism, Museums, and Heritage. Berkeley: University of California Press, 1998.

LOWENTHAL, D. The Heritage Crusade and the Spoils of History. Cambridge: Cambridge University Press, 1998.

MATHERS, C., DARVIL, T., LITTLE, B. J. (eds.) Heritage of Value, Archaeology of Renown: Reshaping Archaeological Assessment and Significance. Gainesville, FL: University Press of Florida, 2005.

MESKELL, L. (ed.) Cosmopolitan Archaeologies. Durham: Duke University Press, 2009.

MESKELL, L., PELS, P. (eds.) Embedding Ethics. Oxford: Berg, 2005.

MORRISON, P., SELMAN, P. Tourism and the environment: a case study from Turkey. The Environmentalist. n. 11(2) p. 113-129, 1991.

ÖZDOĞAN, M. Ideology and archaeology in Turkey. In L. Meskell (ed.) Archaeology under Fire: Nationalism, Politics and Heritage in the Eastern Mediterranean and Middle East. London: Routledge, 1998, p. 111-123.

SHAW, W. M. K. Possessors and Possessed: Museums, Archaeology, and the Visualization of History in the Late Ottoman Empire. Berkeley: University of California Press, 2003.

SHOUP, D. Can archaeology build a dam?: sites and politics in Turkey's Southeast Anatolia Project. Journal of Mediterranean Archaeology. n. 19, p. 231-258, 2006.

SMITH, L. Archaeological Theory and the Politics of Culture. London and New York: Routledge, 2004. . Uses of Heritage. London and New York: Routledge, 2006.

TSING, A. L. Friction: An Ethnography of Global Connection. Princeton: Princeton University Press, 2005. 
UNWTO Tourism Highlights, 2015 Edition. Madrid: World Tourism Organisation, 2015 http://www.e-unwto.org/doi/pdf/10.18111/9789284416899, (accessed on 25.07.2016).

T.C. KÜLTÜR VE TURIZM BAKANLIĞI. Kültür ve Tabiat Varlıklarını Koruma Kanunu No. 2863, 1983.

http://catab.kulturturizm.gov.tr/Eklenti/38041,2863-sayili-kultur-vetabiat-varliklarini-koruma-kanunu-.pdf?0, (accessed on 16.11.2017).

T.C. KÜLTÜR VARLIKLAR VE MÜZELER GENEL MÜDÜRLÜĞÜ. Kültür Varlıklarını Koruma Bölge Kurulu Müdürlükleri, 2013. http://www.kulturvarliklari.gov.tr/TR,43078/kultur-varliklarinikoruma-bolge-kurulu-mudurlukleri.html, (accessed on 12.07.2016).

T.C. BAŞBAKANLIK VAKIFLAR GENEL MÜDÜRLÜĞÜ T.C. Başbakanlık Vakıflar Genel Müdürlüğü Tarihte vakıflar, 2011. http://www.vgm.gov.tr/sayfa.asp x?Id=3 (accessed on 10.07.2016).

TBMM MILLIİ SARAYLAR. TBMM Genel Sekreterliği (Milli Saraylar), 2015. http://www.millisaraylar.gov.tr/portalmain/Management.aspx (accessed on 12.11.2016).

YILMAZ, P. Koruma Yasalarımız ve Patara Antik Kenti, unpublished Master's thesis submitted to Akdeniz University, 1996.

RECEBIDO EM: 01/10/2017 APROVADO EM: 10/12/2017 